\title{
A Meta-Analysis of Extant Literature on Teaching Research Methods: Preliminary Analysis Findings
}

\author{
Mitchell Brown \\ Auburn University \\ Bob Smith \\ National Intelligence University \\ Cameron Thies \\ Arizona State University
}

Paper Prepared for the APSA Teaching \& Learning Conference

Albuquerque, NM

February 7-9, 2020

Abstract: Over the past three decades, an increasing amount of research has been conducted on what techniques and approaches work best to teach research methods to political science students. In this paper, we present the first cut of a meta-analysis of the state of this literature. In this paper we provide an overview of the published works in the primary journals through with political science pedagogy is published, including an overview of what kinds of questions are being asked, by whom, and with what results. Next steps will include attempts to find and examine, to the extent possible, the same for pieces that have not yet been published. Finally, we will pull these together in an attempt to develop a full description of the research about the field and potentially build a technical meta-analysis. 


\section{A Meta-Analysis of Extant Literature on Teaching Research Methods}

(rev 2/3/20)

The Science of Teaching and Learning (SoTL) has emerged as a new and increasingly recognized sub-field of political science in recent years. While pedagogy research has its roots in an era long before political science took an interest in it (see for example the work on pedagogy by John Dewey in the early twentieth century (1997)) and faces controversies over whether it is a science at all (Legemann 2000), the discipline has more recently embraced it.

Political science's interest in pedagogy research tracks that of academia more generally. According to a review by the Association of College and Research Libraries (ACRL, a division of the American Library Association), there are approximately 113 separate journals dedicated solely to pedagogy research for different disciplines within higher education, breaking out by general higher education journals (16), arts and humanities (30), general humanities (21), science and mathematics (23), and social sciences (23). ${ }^{1}$ While this list is not complete in that it does not include journals with multiple foci including pedagogy (e.g., PS: Political Science and Politics) nor does it include related sub-field pedagogy journals (e.g., Journal of Public Affairs Education), the proliferation of these journals underscores higher education's commitment to better understanding how we do what we are designed to do: teach. Figure 1 provides a graph of the start dates of all of these journals.

Comparatively, political science is late to the game. Despite this, interest in how we teach is evident throughout the history of the profession. For example, a year after the inaugural issue of PS: Political Science and Politics it published its first pedagogy pieces. The first was a

\footnotetext{
${ }^{1}$ Accessed from https://acrl.ala.org/IS/instruction-tools-resources-2/pedagogy/a-selected-list-of-journals-onteaching-learning/ on 1/28/20
} 
reflective essay bemoaning the lack of research on how to measure good teaching or "instruction on how to be a good teacher" (Fein 1969). The second pedagogy piece published in PS was a quasi-experiment designed to determine whether students learn more through traditional studying for exams or through preparing for oral exposition of learning through student-based interviews (Hanus 1969).

Among the myriad topics covered by political science pedagogy today, how to teach students to conduct research about the discipline is critically important in two ways. First, teaching about research methods runs parallel to sub-discipline and therefore is applicable to almost all sub-disciplines (excepting, perhaps, normative theory), making it relevant to all political scientists and all of our students. Second, research conducted about teaching the topic itself ought to reflect in important ways the quality of what is happening in the classroom. Despite this, SoTL research about teaching research methods for political science is not robusta cursory examination of all of the pieces published in the Journal of Political Science Education between 2017-2019 shows 8 teaching research methods from $144,{ }^{2}$ or a scant $5.5 \% .^{3}$

To better understand the state of research on teaching research methods, this paper presents the first cut of a larger meta-analysis. We first begin to trace efforts to enhance teaching research methods in political science. We then lay out our approach to developing the larger meta-analysis, followed by a summary of our cursory analysis of the state of knowledge in the field. We conclude with a discussion of the implications of what we have found so far along with an explication of next steps in this project. Our preliminary findings suggest that SoTL research

\footnotetext{
2 This is inclusive of all publications in this time period, including SoTL, instruction, reflection, and book and product review articles.

${ }^{3}$ Our thanks to Auburn University graduate research assistant Zach Mahafza for coding these articles for focus and approach.
} 
on how to teach research methods lags behind what is actually taught in terms of both approach and rigor.

\section{Efforts to Enhance Teaching Research Methods in Political Science}

Efforts to enhance teaching of research methods have proliferated over the past thirty years. In this section, we briefly describe the efforts of the American Political Science Association (APSA) related to supporting teaching generally and pedagogy specifically, discuss the extant journals to support political science pedagogy and pedagogy research, and briefly touch on other efforts that influence our discipline. We use this to conclude with some basic expectations for what we will find in the extant literature.

APSA's role in pedagogy has been active from the start of the association, but the role of methodology in the field and how we teach it has been consistently problematic. For example, in the first state of the discipline book (Finifter 1983), Christopher Achen writes about methodology and teaching that

...political methodologists have expended much of their energies teaching the rest of the discipline new statistical techniques invented in other fields.... Intellectual middlemen have their uses, of course.... But remedial teaching is not scholarship (70).

Indeed, a review of all three of the state of the discipline books published to date demonstrates that teaching and pedagogy has historically been seen as hardly relevant, with the term pedagogy itself showing up only in the 2003 edition, and discussions of teaching across all of the volumes as side mentions to part of the work of accomplished scholars that are highlighted in the volumes. While admittedly the purpose of these books is to chronicle the state of research of the 
field, the fact that there is no mention of research on teaching as part of the discipline quite clearly states the value that has been attributed to this type of work.

But this is not to suggest that APSA has focused solely on research to the exclusion of teaching. Indeed, as early as the 1950s the APSA Committee for the Advancement of Teaching made public statements about the quality of instruction (see for example APSA 1951) and did so indirectly through earlier reports (see for example the 1908 committee report on instruction in government). Note, however, that most of these early efforts were focused primarily on the state of instruction about civics and government in high schools (Ahmad 2017). And as noted above, APSA began distributing literature about teaching to its membership in the 1960s through PS: Political Science and Politics.

This all changed in the early 2000s with the advent of the APSA Teaching and Learning Conference (or TLC) in 2004, created under the leadership of APSA president Michael Britnall. Since that time, the meeting has grown significantly, and though APSA decided to move to a biannual as opposed to annual model, it concurrently rolled the TLC into the association's annual conference and has begun developing other programs to support teaching and pedagogy research for the discipline, including the development of teaching meetings through the Centennial Center, adding the Journal of Political Science Education as an official APSA journal (a product of the success of early TLC meetings), entering into an agreement for a joint international teaching conference, and providing other online products to support teaching for members. APSA has two organized sections related to teaching that work together to produce a regular newsletter, provide teaching awards, and advocate for greater attention and resources for teaching. 
APSA is not alone in advancing the work of teaching in the discipline, but certainly does the most across all of the disciplinary associations. Regional associations like the MPSA and SPSA, and related field associations like ISA and NASPAA, also have teaching sections and make space at their conferences for presentation of this work. Outside of PS: Political Science and Politics and the Journal of Political Science Education there are other peer-reviewed journals that produce pedagogy research, most notably the Journal of Public Affairs Education, among others.

Collectively, these meetings and journals engage to a degree with teaching research methods. Among them, the TLC has consistently included a section related to teaching research methods and has done more than any other effort to support this work. Anecdotally, the research presented at these meetings in particular about teaching research methods focuses primarily on basic statistics, followed by research design, then followed by a smattering of niche interests, and the methods used to engage in SoTL about teaching research methods is in many cases even more nascent than what is being taught.

This points to two themes prevalent in the discipline for teaching research methods. First, there is no method or set of methods per se of the discipline, which is reflected in both what is taught and the pedagogy research we engage in. And second, the level of rigor in how we try to understand what we do is limited. The purpose of this project is two-fold: first, to systematically examine the state of research about teaching methods in political science; and second, to identify a set of studies that can be used to develop a larger meta-analysis focused on what we do know about how to do this. 


\section{Developing a Meta-Analysis}

This paper presents the first snapshot of our attempt to develop a meta-analysis for SoTL research on teaching research methods. A meta-analysis compiles the results of multiple evaluations on the same topic and synthesizes the findings. Oftentimes in experimental research it is impossible to get a sample size large enough to give us adequate statistical power to identify intervention effects. However, if multiple studies have been conducted to examine the same or similar phenomena, they can be pooled and re-examined to reach a stronger conclusion about the results. This is particularly important when similar studies reach different conclusions or there are subgroups within sample sets that we want to examine but we cannot because within each of the studies the $\mathrm{n}$ is too low (Cooper and Lindsay 1998).

There are two ways to go about conducting a meta-analysis, and eventually we hope to do both. The first consists of a systematic review, in which researchers identify all of the possible research conducted on the topic, published or unpublished, determine in advance what information they will glean from each study and follow that plan specifically and without focusing on one study more than on another one (Crombie and Davies 2009; Moher et al 2009). Each component is then systematically analyzed and synthesized to draw conclusions about the phenomenon under investigation. This is what we begin in this paper. The second, more traditional approach, is described above.

As a first step, we are engaged in finding, cataloguing, and coding the extant research on teaching research methods in political science. To date, we have coded 75 published articles and book chapters (not yet exhaustive) published between 1991 and 2019. These articles and book chapters are listed in Appendix A below. 
In addition to the outlet and year of publication, we have variables for each study related to the topic, the authors, the analytic approach, and the findings. Author information coded includes:

- Number of authors

- Gender of the first author (using binary, cis-normative categories)

- Rank at the time of publication of the first author (student status, research fellow, instructor, or types of professor)

- Institution at the time of publication of the first author (high school versus types of institutions of higher education)

Variables coded related to analytic approach include:

- Type of research according to Hamman, Pollock and Wilson (2009)

- Type of analysis (none, summary, non-experimental qualitative, mixed methods, nonexperimental statistical, quasi-experimental, and experimental)

- $\quad$ Sample size

Finally, we have open-ended but not yet coded information about topic and findings. In this paper, we summarize these data and present some initial analyses.

State of Knowledge of the Field

In this section, we review what is being published, where, by whom, and what the evidence base we are using to know about the field looks like. We begin a discussion of what we think we have learned, but those data have not yet been fully coded. We are still missing a good chunk of the literature necessary for a meta-analysis, so everything presented here should be considered preliminary and incomplete (see the conclusion for more discussion). What Is Being Published and Where? 
Figure 2 lays out the count of articles that we have amassed to date by publication outlet. As should be expected since the journal began almost 40 years before JPSE, PS has published the most pieces about teaching research methods, followed by JPSE. ${ }^{4}$ Other outlets include JPAE, book chapters, and an assortment of other disciplinary and non-disciplinary but related sub-field journals (see Appendix A for the full listing).

Over time, the volume of what is being published has significantly increased, though in recent years the annual count of related publications changes. These counts are laid out in Figure 3 over time from 1991 to 2019 and summarized in Table 1. We have broken the publications out into 4 overlapping categories: total publications per year (noted as Count on the figure), the total per year without TLC track summaries (CountNOTrackSumm), the total count without book chapters (CountNOBookChapters), and the total count without TLC track summaries or book chapters (CountNOBCTS). We do this because the track summaries are reports on themes, not actual findings, and account for about a dozen of the total sample, and some of the periodic spikes we see in counts are really driven by the publication of books that include several chapters related to teaching research methods (e.g., Ishiyama et al 2015). For each year and each category of count, the minimum, maximum, and median counts are the same- $-0,7$, and 2 respectively. The mean count changes by category, however. For all, the mean count is 2.5 per year and for the count without the TLC track summaries nor the book chapters the mean count goes down to 1.9 per year. But overall the numbers of articles are trending up over time.

What is being written about is captured in the Focus variable on Table 1. This is broken into seven primary areas: 1) class approach (things like active learning versus problem-based learning); 2) conceptual approach (information literacy, writing, critical thinking; 3) scope and

\footnotetext{
${ }^{4}$ Note that the number of research methods articles coming out of $P S$ is likely to be low, as they began publishing in the late 1960s but our review of the literature does not begin until 1991.
} 
field reviews; 4) teaching quantitative approaches; 5) teaching tools (books, software, etc.); 6) student psychological factors (math phobia, efficacy); and 7) track summaries. Among these, the most frequent are class approach, followed by scope and field reviews and then quantitative methods.

By Whom?

We also examined who is writing about teaching research methods - these variables are captured in Table 2. A small majority of the authors are female (as the lead author), associate professors, and from $\mathrm{PhD}$ granting universities. The number of authors range from 1 to 4 , and most have two co-authors. Note that all of this information is collected and coded for the year of the publication.

We also examined relationships between author characteristics (captured on Table 3). There are very few statistically significant relationships, though the ones we do find are quite interesting. First, male authors are more likely than female authors to write alone, and female authors are most likely to write with one other female (analysis not shown). There are a surprising number of graduate students who are first author - and usually in these cases there are more authors and they are from $\mathrm{PhD}$ granting institutions.

What Is the Evidence Base?

Based on our first review of the data, we find little true SoTL research about teaching research methods, and the research that that falls in this category does not begin to be published until 2008, showing up sporadically after that point. While impossible to establish actual causality from this analysis, that the timing of the first true SoTL research coincides proximately after the advent of the TLC making it is safe to assume that this body of knowledge is a direct result of APSA's TLC. 
The research type (think design with an overlay of pedagogy) and analytic approach taken in these pieces varies. Most of the pieces are some kind of review of personal experience in the classroom or case study of an innovative teaching technique, usually often first person with some basic statistics about participation and teaching evaluations. SoTL and state of the field reviews follow this. In terms of analytic approach, most include some form of basic quantitative analysis, usually stopping at the level of bivariate analysis. There are very few true experiments. Of the quantitative studies, the sample sizes range from 5-450, with a median of 71 and a mean of 95 . Focus and research tight are strongly largely because one of the substantive categories match. And there is a relationship between sample size and analytic approach—with the larger samples more able to support multivariate analysis.

Based on our analysis of bivariate relationships, we also attempted to model what may drive different design approaches to pedagogy research for methods in political science. Using the research type variable for our dependent variable and multinomial logistic regression analysis, we model the effects of quantitative versus all other types of analysis (collapsed from the analytic approach variable), number of authors, and year of publication, and institution type. The results can be found on Table 4, though note that the analysis is preliminary and there are problems with the model. If the results are to be believed, the effect of these variables can be seen mostly on the category of reports on personal experience, which are less likely to use any quantitative analysis, have fewer authors, consist of earlier pieces, and are more likely to be written by authors not from $\mathrm{PhD}$ granting institutions. We see moderate effects on increased numbers of co-authors for SoTL pieces, and increased number of authors on field review pieces and scholarly teaching pieces. What Do We (Think We) Know? 


\section{Conclusions: Next Steps \& How to Move Forward as a Field}

In this paper, we take a first cut at examining 30 years of articles about teaching research methods in political science, relying on disciplinary and related journals and available book chapters. We have not yet included unpublished studies, nor have we completed an extensive review of book chapters. These pieces have been compiled to eventually develop a systematic review of findings in the field and a meta-analysis of similar studies.

In this first cut of the available data, we think we know a few things. There is little rigorous study about teaching research methods even after over a decade of JPSE and 15 years of the APSA TLC. This is hardly surprising given how late political science as a discipline came to focusing in a serious way on pedagogy. However, it appears that the TLC is at least a proximate cause of more research in this area, spurred along by the creation of JPSE. Most of this work is being done by females as well as tenure track scholars. The number of publications from faculty in $\mathrm{PhD}$ granting institutions was surprising - though perhaps this reflects publication bias more so than interest from people in other types of institutions, as anecdotal evidence from attendance in teaching section panels at conferences would suggest. This is not to suggest that pedagogy outlets favor articles from $\mathrm{PhD}$ granting institutions, but rather these authors have more time in schedules to and likely more experience in navigating the peer review process and thus have more success in this area than scholars from non-PhD granting institutions.

Finally, there are several next steps in this project, and we lay them out here in the hopes that readers may be able to offer some contributions. These include:

1. Identifying other publications about teaching research methods in political science. These may come from:

a. Other academic journals 
b. Edited volumes

c. Books

2. Identifying other research done about teaching research methods in political science that have not been published. These may come from:

a. Manuscripts that have been submitted but were rejected or received a revise and resubmit which was never completed

b. Manuscripts and conference papers that have not been submitted but are complete (these may be identifiable from conference proceedings)

3. Coding and analysis of these additional articles for themes similar to those presented in this paper (see State of Knowledge of the Field discussed above).

4. Identify common questions among the quantitative studies to develop a meta-analysis from the available data.

All of this work is on-going, but to the extent that readers can assist with any of this, especially steps 1 and 2, we encourage them to reach out to us. 


\section{Works Cited}

American Political Science Association. 1908. Report of the Committee on Instruction in Government.

American Political Science Association Committee for the Advancement of Teaching. 1951. Goals for Political Science. New York: William Sloane Associates.

Ahmad, Iftikhar. 2017. "Political Science and the Good Citizen: The Genealogy of Traditionalist Paradigm of Citizenship Education in the American School Curriculum." Journal of Social Science Education. 16(4): 38-48.

Cooper, Harris M. and James J. Lindsay. 1998. "Research Synthesis and Meta-analysis.” In Len Bickman and Debra Rog, Eds. Thousand Oaks: Sage Publishers

Crombie, Iain K. and Huw T Davies. 2009. “What Is Meta-Analysis?” $2^{\text {nd }}$ Edition. Accessed from https://www.whatisseries.co.uk.

Dewey, John. 1997. Democracy and Education: An Introduction to the Philosophy of Education. Washington, DC: The Free Press.

Fein, Leonard J. 1969. “Teaching Political Science.” PS: Political Science and Politics. 2(3): 303-307.

Finifter, Ada W., Ed. 1993. Political Science: The State of the Discipline II. Washington, DC: The American Political Science Association.

Finifter, Ada W., Ed. 1983. Political Science: The State of the Discipline. Washington, DC: The American Political Science Association.

Hamman, Kerstin; Phillip H. Pollock; and Bruce M. Wilson. 2009. "Who SoTLs Where?

Publishing the Scholarship of Teaching and Learning in Political Science." PS: Political Science and Politics. 45(3): 729-735.

Hanus, Herome J. 1969. “An Experiment in Individualized Instruction in Political Science.” PS: Political Science and Politics. 2(4): 600-201.

Ishiyama, John; Will Miller; and Eszter Simon, Eds. 2015. Handbook of Teaching and Learning in Political Science and International Relations. Northampton, MA: Edward Elgar Publishers.

Katznelson, Ira and Helen V. Milner, Eds. 2003. Political Science: The State of the Discipline Centenniel Edition. New York: W. W. Norton \& Company \& Washington, DC: The American Political Science Association. 
Legemann, Ellen Condliffe. 2000. An Elusive Science: The Troubling History of Education Research. Chicago: The University of Chicago Press.

Moher, David; Alessandro Liberati; Jennifer Tetzlaff; Douglas G. Altman; and the PRISMA Group, 2009. "Preferred Reporting Items for Systematic Reviews and Meta-Analyses: The PRISMA Statement." Journal of Clinical Epidemiology. 62: 1006-1012. 
Figure 1. New Pedagogy Journals

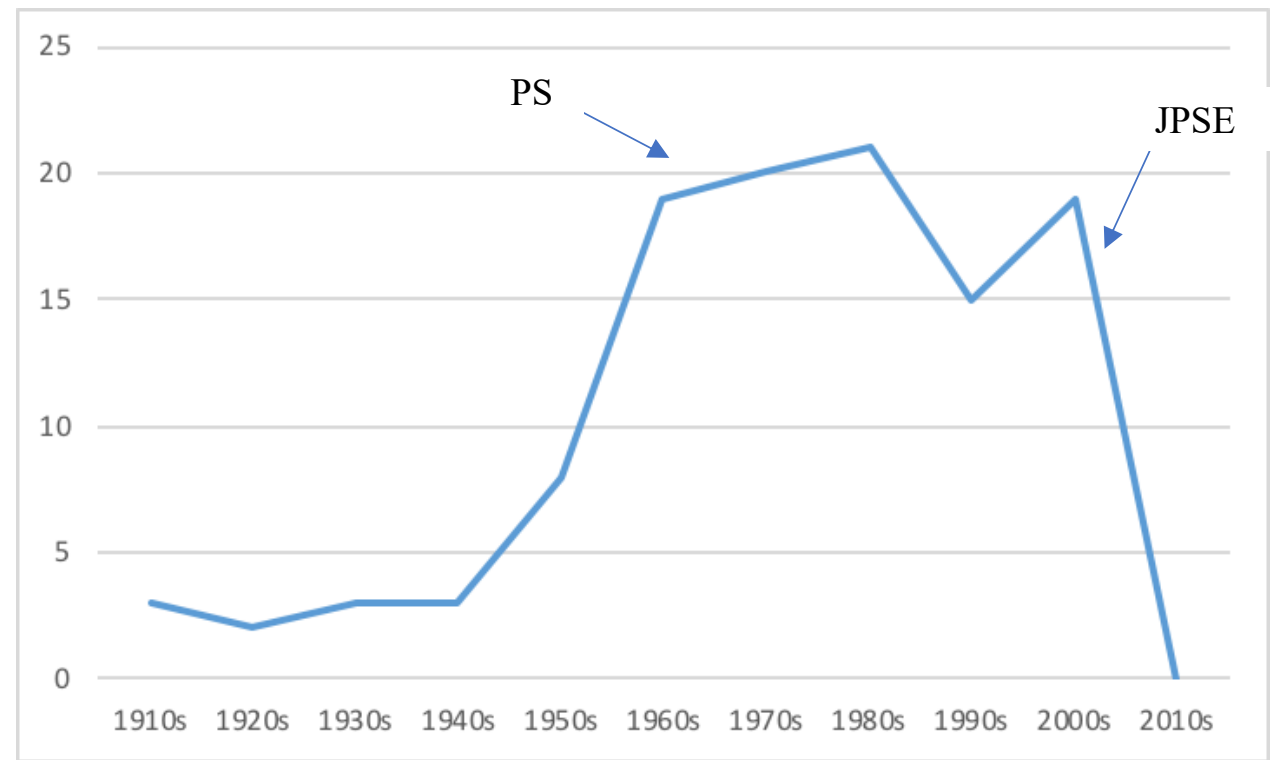


Figure 2. Articles by Outlet

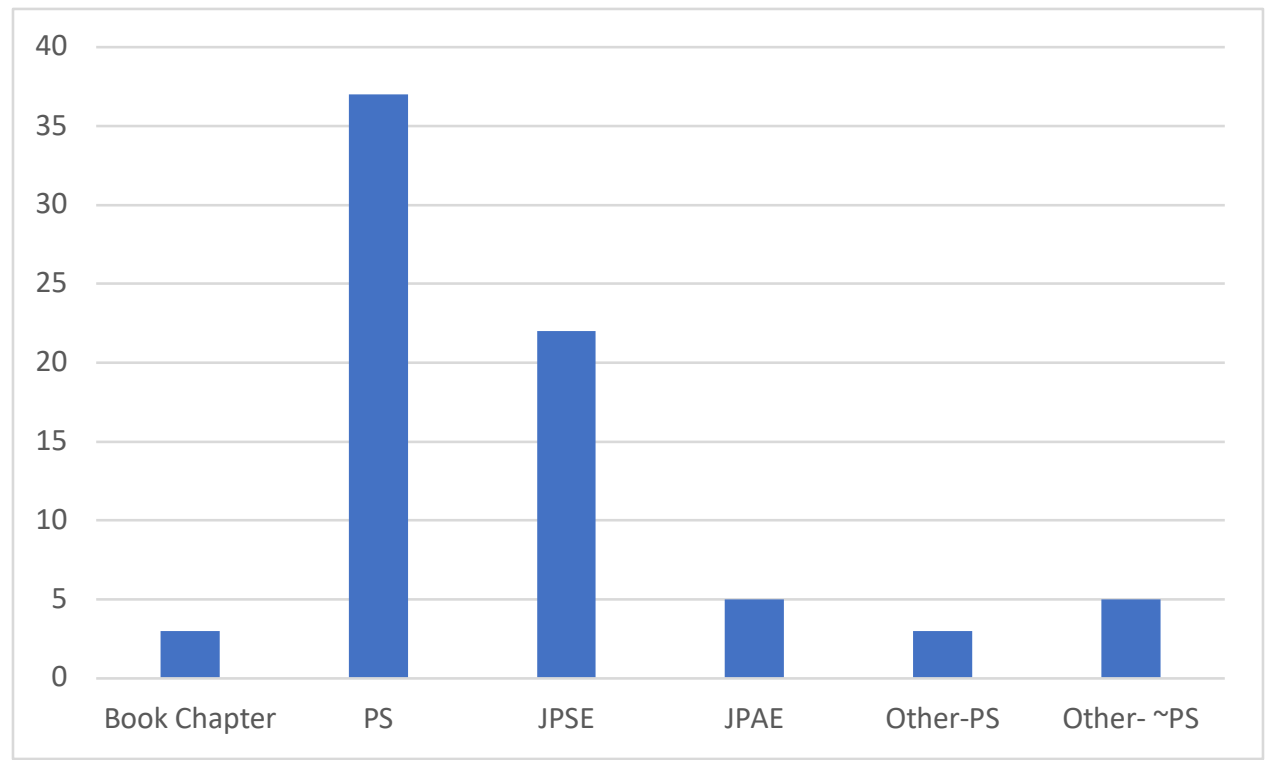


Figure 3. Articles over Time

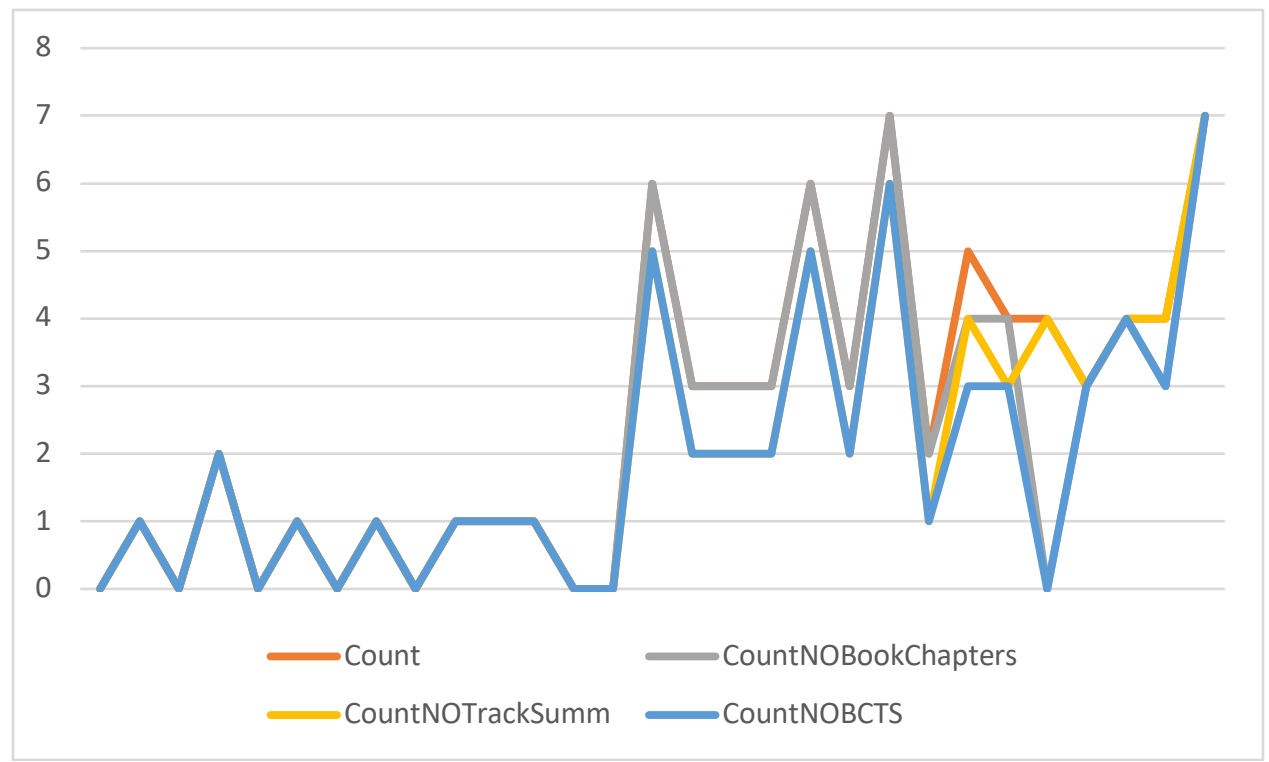


Table 1. Descriptive Overview of Article Research Approach

\begin{tabular}{|c|c|c|c|}
\hline Variable & \multicolumn{2}{|c|}{ Measure of Dispersion } & $\begin{array}{c}\text { Measure of Central } \\
\text { Tendency }\end{array}$ \\
\hline Publications per Year & Range & $0-7$ & $\begin{array}{l}\text { Median }=2 \\
\text { Mean }=2.5\end{array}$ \\
\hline Focus & $\begin{array}{r}\text { Class approach } \\
\text { Conceptual approach } \\
\text { Scope/field } \\
\text { Quantitative methods } \\
\text { Tools } \\
\text { Student development } \\
\text { Track summaries }\end{array}$ & $\begin{array}{c}24.3 \% \\
12.2 \% \\
20.3 \% \\
16.2 \% \\
5.4 \% \\
8.1 \% \\
13.5 \%\end{array}$ & $\begin{array}{c}\text { Mode }=\text { classroom } \\
\text { approach }\end{array}$ \\
\hline Research Type & $\begin{array}{r}\text { SoTL } \\
\text { Personal experience } \\
\text { Innovative technique } \\
\text { Scholarly teaching } \\
\text { State of the field review } \\
\text { Other }\end{array}$ & $\begin{array}{c}18.9 \% \\
21.6 \% \\
21.6 \% \\
9.8 \% \\
17.6 \% \\
13.7 \%\end{array}$ & $\begin{array}{c}\text { Bi-modal= personal } \\
\text { experience AND } \\
\text { innovative technique }\end{array}$ \\
\hline Analytic Approach & $\begin{array}{r}\text { Non-analytical } \\
\text { Qualitative } \\
\text { Mixed methods } \\
\text { Non-experimental } \\
\text { - descriptive stats } \\
-\quad \text { bivariate } \\
\text { multivariate } \\
\text { Quasi-experimental } \\
\text { Experimental }\end{array}$ & $\begin{array}{c}12.2 \% \\
12.2 \% \\
12.2 \% \\
2.4 \% \\
9.8 \% \\
17.1 \% \\
4.9 \% \\
2.4 \% \\
4.9 \%\end{array}$ & $\begin{array}{l}\text { Mode }=\text { non- } \\
\text { experimental } \\
\text { statistical analysis up } \\
\text { to the examination of } \\
\text { bivariate relationships }\end{array}$ \\
\hline Sample Size & Range & $5-450$ & $\begin{array}{c}\text { Median }=71 \\
\text { Mean }=95 \\
\text { St. Dev. }=97.8\end{array}$ \\
\hline
\end{tabular}


Table 2. Descriptive Overview of Author Information

\begin{tabular}{|c|c|c|c|}
\hline Variable & \multicolumn{2}{|c|}{ Measure of Dispersion } & $\begin{array}{c}\text { Measure of Central } \\
\text { Tendency }\end{array}$ \\
\hline Number of Authors & Range & $1-4$ & Median $=2$ \\
\hline Gender (Lead Author) & $\begin{array}{r}\text { Male } \\
\text { Female }\end{array}$ & $\begin{array}{l}45.9 \% \\
54.1 \%\end{array}$ & Mode $=$ Female \\
\hline Rank (Lead Author) & $\begin{array}{r}\text { Undergraduate } \\
\text { Graduate } \\
\text { Research Fellow } \\
\text { Assistant Professor } \\
\text { Associate Professor } \\
\text { Professor }(40)\end{array}$ & $\begin{array}{c}1.8 \% \\
1.8 \% \\
7.0 \% \\
31.5 \% \\
35.1 \% \\
24.6 \%\end{array}$ & $\begin{array}{c}\text { Mode }=\text { Associate } \\
\text { Professor }\end{array}$ \\
\hline $\begin{array}{l}\text { Institution Type } \\
\text { (Lead Author) }\end{array}$ & $\begin{array}{r}\text { High School } \\
\text { Community College } \\
\text { BA/BS } \\
\mathrm{MA} \\
\mathrm{PhD}\end{array}$ & $\begin{array}{c}0 \% \\
1.4 \% \\
8.1 \% \\
6.8 \% \\
56.8 \% \\
27.0 \%\end{array}$ & $\begin{array}{c}\text { Mode }=\text { PhD Granting } \\
\text { Institution }\end{array}$ \\
\hline
\end{tabular}


Table 3. Bivariate Relationships between Author Characteristics and Analytic Approach

\begin{tabular}{|c|c|c|}
\hline Variable 1 & by Variable 2 & Statistic \\
\hline \multirow[t]{7}{*}{ Gender } & Rank & $\chi^{2}=5.047$ \\
\hline & Institution & $\chi^{2}=5.176$ \\
\hline & Number of authors & $\chi^{2}=15.472 * * *$ \\
\hline & Year & $F=0.010$ \\
\hline & Research Type & $\chi^{2}=0.196$ \\
\hline & & $F=0.430$ \\
\hline & Focus & $\chi^{2}=9.039$ \\
\hline \multirow[t]{4}{*}{ Rank } & Number of authors & $\chi^{2}=11.752$ \\
\hline & Institution & $\chi^{2}=21.148$ \\
\hline & & $F=0.63$ \\
\hline & Focus & $\chi^{2}=27.009$ \\
\hline \multirow[t]{8}{*}{ Analytic Approach } & Gender & $\chi^{2}=8.137$ \\
\hline & Rank & $\chi^{2}=32.258$ \\
\hline & Institution & $\chi^{2}=12.421$ \\
\hline & Number of authors & $\chi^{2}=18.062$ \\
\hline & Year & $F=1.820$ \\
\hline & Research Type & $\chi^{2}=54.692$ \\
\hline & & $F=4.24 * *$ \\
\hline & Focus & $\chi^{2}=42.387$ \\
\hline \multirow[t]{7}{*}{ Research Type } & Gender & $\chi^{2}=8.196$ \\
\hline & Rank & $\chi^{2}=20.076$ \\
\hline & Institution & $\chi^{2}=17.528$ \\
\hline & Number of authors & $\chi^{2}=24.957^{*}$ \\
\hline & Year & $F=0.61$ \\
\hline & & $F=2.12$ \\
\hline & Focus & $\chi^{2}=46.918^{* * *}$ \\
\hline
\end{tabular}

* $\quad$ significant at $\mathrm{p}<.05$

$* * \quad$ significant at $\mathrm{p}<.01$

$* * * \quad$ significant at $\mathrm{p}<.001$ 
Table 4. Multinomial Analysis of Research Type for Teaching Methods

\begin{tabular}{|c|c|c|}
\hline Category & Variables & Coefficients \\
\hline \multirow[t]{5}{*}{ SoTL Research } & Quantitative analysis & $0.024(1.067)$ \\
\hline & Number of authors & $1.045(0.788)^{*}$ \\
\hline & Year published & $0.112(0.090)$ \\
\hline & Institution & $-0.186(0.721)$ \\
\hline & Constant & $-226.567(182.072)$ \\
\hline \multirow{5}{*}{$\begin{array}{l}\text { Reports on Personal } \\
\text { Experience }\end{array}$} & Quantitative analysis & $-4.551(1.931)^{* * *}$ \\
\hline & Number of authors & $-6.132(3.534) * *$ \\
\hline & Year published & $-0.152(0.119)^{*}$ \\
\hline & Institution & $-2.799(1.742)^{*}$ \\
\hline & Constant & $325.241(243.368)^{*}$ \\
\hline \multirow[t]{5}{*}{ Scholarly Teaching } & Quantitative analysis & $0.516(1.450)$ \\
\hline & Number of authors & $0.976(0.906)$ \\
\hline & Year published & $-0.013(0.078)$ \\
\hline & Institution & $-0.076(0.896)$ \\
\hline & Constant & $24.449(157.215)$ \\
\hline \multirow[t]{5}{*}{ State of the Field Reviews } & Quantitative analysis & $1.266(1.411)$ \\
\hline & Number of authors & $1.789(0.787)^{* *}$ \\
\hline & Year published & $0.035(0.077)$ \\
\hline & Institution & $0.220(0.822)$ \\
\hline & Constant & $-74.931(154.606)$ \\
\hline \multicolumn{3}{|l|}{$\mathrm{n}=52$} \\
\hline \multicolumn{3}{|l|}{ Chi- $2=46.46 p<0.001$} \\
\hline \multicolumn{3}{|l|}{ Pseudo R2 $=0.254$} \\
\hline \multicolumn{3}{|c|}{ Base outcome $=$ Innovative teaching } \\
\hline \multicolumn{3}{|c|}{ * $\quad$ significant at $\mathrm{p}<.10$ using a one-tailed test } \\
\hline \multicolumn{3}{|c|}{ ** $\quad$ significant at $\mathrm{p}<.05$ using a one-tailed test } \\
\hline significant at $\mathrm{p}<.01 \mathrm{u}$ & a one-tailed test & \\
\hline
\end{tabular}




\section{Appendix A: Listing of Articles}

Aguado, N. Alexander. 2009. "Teaching Research Methods: Learning by Doing." Journal of Public Affairs Education. 15(2): 251-260.

Andersen, Kristi and Dana Michael Harsell. 2005. "Assessing the Impact of a Quantitative Skills Course for Undergraduates.” Journal of Political Science Education. 1:17-27.

Aristigueta, Maria P. and Jeffrey A. Faffel. 2001. "Teaching Techniques of Analysis in the MPA Curriculum: Research Methods, Management Science, and 'The Third Path'." Journal of Public Affairs Education. 7(3): 161-169.

Babst, Gordon et al. 2006. "2006 APSA Teaching and Learning Conference Track Summaries.” PS: Political Science and Politics. 39(3): 533-544.

Baglione, Lisa. 2008. "Doing Good and Doing Well: Teaching Research-Paper Writing by Unpacking the Paper.” PS: Political Science and Politics.

Bailey, Michael A. 2019. "Teaching Statistics: Going from Scary, Boring, and Useless to, Well, Something Better.” PS: Political Science and Politics. 52(2): 367-370.

Bennion, Elizabeth A. et al. 2009. "2009 APSA Teaching and Learning Conference Track Summaries.” PS: Political Science and Politics. 42(3): 575-587.

Bergbower, Matthew L. 2017. "When Are Students Ready for Research Methods? A Curriculum Mapping Argument for the Political Science Major." Journal of Political Science Education. 13(2): 200-210.

Bernstein, Jeffrey and Brooke Allen. 2013. "Overcoming Methods Anxiety: Qualitative First, Quantitative Next, Frequent Feedback Along the Way." Journal of Political Science Education. 9(1): 1-15.

Botteron, Cynthia A. and S. Suzan J. Harkness. 2005. "Track Five: Research Methods and Techniques.” PS: Political Science \& Politics. 38:3.

Bos, Angela L. and Monica C. Schneider. 2009. "Stepping around the Brick Wall: Overcoming Student Obstacles in Methods Courses." PS: Political Science and Politics. 42(2): 375-383.

Box-Steffensmeier, Janet M. and Anand E. Sokhey. 2007. “A Dynamic Labor Market: How Political Science is Opening up to Methodologists, and How Methodologists Are Opening up Political Science.” PS: Political Science and Politics. 40(1): 125-127.

Brown, Mitchell. 2015. "Graduate Research Methods.” In Ishiyama, John; Will Miller; and Eszter Simon, Eds. Handbook of Teaching and Learning in Political Science and International Relations. Northampton, MA: Edward Elgar Publishers. 
Brown, Mitchell. 2013. "Cross-Integration of Community, Research, and the Classroom: Extensions of a National Evaluation.” In Baker, Hale and Summerfield, Eds. Scholarship in Action: Community, Leaders and Citizens. Common Grounds Books: Chicago, IL.

Brown, Mitchell et al. 2007. "2007 APSA Teaching and Learning Conference Track Summaries.” PS: Political Science \& Politics. 40(3): 575-588.

Buchler, Justin. 2009. "Teaching Quantitative Methodology to the Math Averse.” PS: Political Science \& Politics. 42(3): 527-30.

Carsey, Thomas M. and Jeffrey J. Harden. 2015. "Can You Repeat That Please?: Using Monte Carlo Simulation in Graduate Quantitative Research Methods Classes.” Journal of Political Science Education. 11(1): 94-107.

Centellas, Miguel. 2011. "Preaching What We Practice: Bringing Scope and Methods 'Back In'.” PS: Political Science \& Politics. 44(4): 817-822.

Clark, Alistair. 2011. "Embedding Transferable Skills and Enhancing Student Learning in a Political Science Research Methods Module: Evidence from the United Kingdom.” PS: Political Science \& Politics. 44(1): 135-139.

Combes, Nathan J. 2019. "Targeting Conceptual Understanding: How to Improve Learning and Course Retention in Research Methods Courses." Journal of Political Science Education. 15(3): 281-298.

Currin-Percival, Mary and Martin Johnson. 2010. "Understanding Sample Surveys: Selective Learning about Social Science Research Methods.” PS: Political Science \& Politics. 43: 533-40.

Dickovick, J. Tyler. 2009. "Methods in the Madness: Integrative Approaches to Methodology in Introductory Comparative Politics.” Journal of Political Science Education. 5(2): 138-153.

Doherty, David. 2011. “Teaching Experimental Methods: A Framework for Hands-on Modules.” Journal of Political Science Education. 7(2): 163-172.

Elman, Colin; Diana Kapiszewski; and Dessislava Kirilova. 2015. "Learning through Research: Using Data to Train Undergraduates in Qualitative Methods." PS: Political Science and Politics.

Fisher, Sarah and Florian Justwan. 2018. "Scaffolding Assignments and Activities for Undergraduate Research Methods.” Journal of Political Science Education. 14(1):63-71.

Fitzgerald, Jennifer and Vanessa Baird. 2011. "Taking a Step Back: Teaching Critical Thinking by Distinguishing Appropriate Types of Evidence." PS: Political Science \& Politics. 44: 619-24.

Fitzpatrick, Jody. 2000. "What Are Our Goals in Teaching Research Methods to Public Administrators?" Journal of Public Affairs Education. 6(3): 173-181. 
Fletcher, Joseph F. and Michael A. Painter-Main. 2014. "An Elephant in the Room: Bias in Evaluating a Required Quantitative Methods Course.” Journal of Political Science Education. 10:121-135.

Flink, Tim and David Kaldewey. 2018. "The Language of Science Policy in the Twenty-First Century: What Comes after Basic and Applied Research?" In Kaldewey, David and Desiree Schauz, Eds. Basic and Applied Research: The Language of Science Policy in the Twentieth Century. Berghahn Books.

Garaffa, Tyler and Craig Leonard Brians. 2011. "Two Views of a Conference Presentation: An Undergraduate's First Research Conference Experience.” Journal of Political Science Education. 7(2): 240-242.

Gilbert, Julie K.; Katherine Knutson; and Christopher P. Gilbert. 2012. "Adding an Integrated Library Component to an Undergraduate Research Methods Course." PS: Political Science and Politics. 45(1): 112-118.

Hail, Michael W. et al. 2008. “2008 APSA Teaching and Learning Track Summaries.” PS: Political Science and Politics. 41(3): 613-627.

Hamman, Kerstin; Phillip H. Pollock; and Bruce M. Wilson. 2009. "Who SoTLs Where? Publishing the Scholarship of Teaching and Learning in Political Science." PS: Political Science and Politics. 45(3): 729-735.

Henshaw, Alexis Leanna and Scott R. Meinke. 2018. "Data Analysis and Data Visualization as Active Learning in Political Science." Journal of Political Science Education. 14(4): 423-439.

Hill, Kim Quaile and Rebekah Myers. 2014. "Scientific Literacy in Undergraduate Political Science Education: The Current State of Affairs, an Agenda for Action, and Proposed Fundamental Benchmarks.” PS: Political Science and Politics. 47(4): 835-839.

Howard, Tiffiany O.; Mary-Ann Winkelmes; and Marya Shegog. 2019. “Transparency Teaching in the Virtual Classroom: Assessing the Opportunities and Challenges of Integrating Transparency Teaching Methods with Online Learning." Journal of Political Science Education.

Hubbell, Larry. 1994. "Teaching Research Methods: An Experiential and Heterodoxical Approach.” PS: Political Science and Politics. 27(1):60-64.

Kilburn, Daniel; Melanie Nind: and Rose Wiles. 2014. "Learning as Researchers and Teachers: The Development of a Pedagogical Culture for Social Science Research Methods?" British Journal of Educational Studies. 62(2): 191-207.

Kollars, Nina and Amanda M. Rosen. 2017. "Who's Afraid of the Big Bad Methods? Methodological Games and Role Play.” Journal of Political Science Education. 13(3): 333-345. 
Leston-Bandeira, Cristina. 2015. "Teaching Undergraduate Research Methods." In Ishiyama, John; Will Miller; and Eszter Simon, Eds. Handbook of Teaching and Learning in Political Science and International Relations. Northampton, MA: Edward Elgar Publishers.

Lewthwaite, Sarah and Melanie Nind. 2016. "Teaching Research Methods in the Social Sciences: Expert Perspectives on Pedagogy and Practice." British Journal of Educational Studies. 64(4): 413-430.

Lovell, Darrell. 2019. "Promoting Original Research: Designing a Course to Produce Quality Undergraduate Political Science Research in the Community College." Journal of Political Science Education. 15(3): 392-398.

Maier, Scott R. and Patricia A. Curtin. 2005. "Self-Efficacy Theory: A Prescriptive Model for Teaching Research Methods." Journalism \& Mass Communication Educator. 59:4.

Marfleet, B. Gregory and Brian J. Dille. 2005. "Information Literacy and the Undergraduate Research Methods Curriculum” Journal of Political Science Education. 1(2): 175-190.

Mariani, Mack; Fiona Buckley; Theresa Reidy; and Richard Witmer. 2013. "Promoting Student Learning and Scholarship through Undergraduate Research Journals." PS: Political Science \& Politics. 46(4): 830-835.

Martinek, Wendy L. 2017. "A Review of Textbooks for Teaching Graduate Research Methods." PS: Political Science and Politics. 554-558.

McBride, Allan B. 1996. "Creating a Critical Thinking Learning Environment: Teaching Statistics to Social Science Undergraduates." PS: Political Science and Politics. 29(3): 517-521.

McBride, Allan B. 1994. "Teaching Research Methods Using Appropriate Technology.” PS: Political Science and Politics. 27(3): 553-557.

Mealy, Kimberly A. et al. 2014. "2014 APSA Teaching and Learning Conference and Track Summaries." PS: Political Science and Politics. 47(3):711-730.

Mealy, Kimberly A. et al. 2013. "2013 APSA Teaching and Learning Conference Track Summaries." PS: Political Science \& Politics. 46(3): 643-663.

Mealy, Kimberly A. et al. 2012. "2012 APSA Teaching and Learning Conference Track Summaries.” PS: Political Science and Politics. 45(3): 521-540.

Mealy, Kimberly A. et al. 2011. "2011 APSA Teaching and Learning Conference Track Summaries.” PS: Political Science \& Politics. 44(3): 653-667.

Mealy, Kimberly A. et al. 2010. "2010 APSA Teaching and Learning Conference Track Summaries." PS: Political Science \& Politics. 43(3): 567-580. 
Monogan III, James E. 2017. “A Review of Textbooks for Teaching Undergraduate Methods.” PS: Political Science and Politics.

Murphy, Chad. 2015. "The Use of Peer Modeling to Increase Self-Efficacy in Research Methods Courses." Journal of Political Science Education. 11(1):78-93.

Ni, Anna Ya. 2013. "Comparing the Effectiveness of Classroom and Online Learning: Teaching Research Methods.” Journal of Public Affairs Education. 19(2): 199-215.

Oldmixon, Elizabeth A. 2018. “'It Was My Understanding That There Would Be No Math': Using Thematic Cases to Teach Undergraduate Research Methods." Journal of Political Science Education. 14(2): 249-259.

Parker, Jonathan. 2010. "Undergraduate Research-Methods Training in Political Science: A Comparative Perspective.” PS: Political Science and Politics. 43(1): 121-125.

Powner, Leanne C. 2006. "Teaching the Scientific Method in the Active Learning Classroom." PS: Political Science and Politics. 39(3): 521-524.

Roberts, James C. 2015. "Evaluating the Effectiveness of Lecture Capture: Lessons Learned from an Undergraduate Political Research Class." Journal of Political Science Education. 11(1): 45-60.

Rodgers, Pamela H. and Cecilia Manrique. 1992. "The Dilemma of Teaching Political Science Research Methods: How Much Computers? How Much Statistics? How Much Methods?" PS: Political Science and Politics. 25(2):234-237.

Rom, Mark Carl. 2015. "Numbers, Pictures, and Politics: Teaching Research Methods Through Data Visualizations.” Journal of Political Science Education. 11(1): 11-27.

Rubaii, Nadia. 2019. "Why Research Methods Matter: Essential Skills for Decision-Making." Journal of Public Affairs Education. 25(2): 277-279.

Ryan, Matt; Clare Saunders; Emily Rainsford; and Emma Thompson. 2014. "Improving Research Methods Teaching and Learning in Politics and International Relations: A 'Reality Show' Approach.” Politics. 34(1): 85-97.

Scott, James M. 2015. "Developing Student Scholars: Best Practices in Promoting Undergraduate Research.” In Ishiyama, John; Will Miller; and Eszter Simon, Eds. Handbook of Teaching and Learning in Political Science and International Relations. Northampton, MA: Edward Elgar Publishers.

Schwartz-Shea, Peregrine and Dvora Yanow. 2002. "'Reading' 'Methods' 'Texts': How Research Methods Texts Construct Political Science.” Political Research Quarterly. 55(2): 457486. 
Shannon, Amanda and Vaughn Shannon. 2016. "Librarians in the Midst: Improving Student Research Through Collaborative Instruction.” Journal of Political Science Education. 12(4): 457-470.

Siver, Christi; Seth W. Greenfest; and G. Claire Haeg. 2016. "Are We Teaching Them Anything?: A Model for Measuring Methodology Skills in the Political Science Major." Journal of Political Science Education. 12(2): 186-199.

Smith, Ron P. 1998. "Quantitative Methods in Peace Research.” Journal of Peace Research. 35(4): 419-427.

Spronken-Smith, Rachel. 2005. "Implementing a Problem-Based Learning Approach for Teaching Research Methods in Geography." Journal of Geography in Higher Education. 29:203-221.

Thies, Cameron G. and Robert E. Hogan. 2005. "The State of Undergraduate Research Methods Training in Political Science.” PS: Political Science and Politics. 38(2): 293-297.

Thornton, Stephen. 2015. "Promoting Information Literacy and Information Research." In Ishiyama, John; Will Miller; and Eszter Simon, Eds. Handbook of Teaching and Learning in Political Science and International Relations. Northampton, MA: Edward Elgar Publishers.

Turner, Charles C. and Cameron G. Thies. 2009. "What We Mean by Scope and Methods: A Survey of Undergraduate Scope and Methods Courses." PS: Political Science and Politics. 42(2): 367-373.

Van der Swan, Natascha and Alexandre Afonso. 2019. "Activating the Research Methods Curriclum: A Blended Flipped Classroom.” PS: Political Science and Politics. 52(4): 749-753.

Wagner, Claire; Mark Garner; and Barbara Kawulich. 2011. "The State of the Art of Teaching Research Methods in the Social Sciences: Towards a Pedagogical Culture." Studies in Higher Education. 36(1): 75-88.

Williams, Michelle Hale and Jocelyn Jones Evans. 2008. "Factors in Information Literacy Education.” Journal of Political Science Education. 4(1): 116-130.

Williams, Michelle Hale; Kymberly Ann Goodson; and W. Gary Howard. 2006. "Weighing the Research Paper Option: The Difference That Information Literacy Skills Can Make.” PS:

Political Science and Politics. 39(3): 513-519.

Wilson, Steven L. and Yoshiko M. Herrera. 2019. "Teaching Computerized Content Analysis for Undergraduate Research Papers.” PS: Political Science and Politics. 52(3): 536-542.

Yanow, Dvora and Peregrine Schwartz-Shea. 2007. "The Methods Café: An Innovative Idea for Methods Teaching at Conference Meetings." PS: Political Science and Politics. 40(2): 383-386. 